\title{
Persistence of the red ring nematode in the roots and in the rhizosphere of recently eradicated coconut palms
}

\section{Persistência do nematoide do anel vermelho nas raízes e na rizosfera de coqueiros recém-erradicados}

\author{
Adriana Neutzling Bierhals ${ }^{1 *}$; Daniel da Silva Torres ${ }^{1}$; \\ Adriana Guimarães Duarte²; Anderson Carlos Marafon ${ }^{3}$
}

\begin{abstract}
Red ring disease is one of the primary diseases that attacks the coconut palm (Cocos nucifera L.) in Brazil. This lethal disease is caused by a nematode (Bursaphelenchus cocophilus) and can spread via contaminated tools or by the South American palm weevil (Rhynchophorus palmarum). The goal of this research was to determine the persistence of nematodes within the roots and the rhizosphere of recently eradicated coconut palms, cultivated in the coastal region of the state of Alagoas. Soil and root samples from coconut palms with advanced symptoms of red ring disease were collected up to 6 months after the eradication of the plants. Sample processing was conducted at the Ecology and Insect Behavior Laboratory of the Federal University of Alagoas. Sample collection was ended when B. cocophilus were no longer found in the laboratory tests. B. cocophilus were able to survive in the coconut palm roots for at least 118 and 133 days after felling (DAF), in Coruripe and São Miguel dos Milagres, respectively. B. cocophilus could migrated from the roots to the soil, where they were found until 76 and $88 \mathrm{DAF}$, in Coruripe and São Miguel dos Milagres, respectively.
\end{abstract}

Key words: Bursaphelenchus cocophilus. Cocos nucifera. Red ring disease. Survival time.

\section{Resumo}

Dentre as principais moléstias que atacam o coqueiro encontra-se o anel vermelho, doença letal causada pelo nematoide Bursaphelenchus cocophilus, o qual pode ser disseminada por ferramentas contaminadas ou através da broca-do-olho-do-coqueiro, Rhynchophorus palmarum. Neste contexto, o presente trabalho de pesquisa teve como objetivo determinar a persistência de nematoides associados à rizosfera de coqueiros recém-erradicados, cultivados na região da Baixada Litorânea do Estado de Alagoas. Foram coletadas amostras de solo e de raízes de coqueiros com sintomas avançados da doença do anel vermelho até seis meses após a erradicação das plantas. O processamento das amostras foi realizado no Laboratório de Ecologia e Comportamento dos Insetos da Universidade Federal de Alagoas. A coleta de amostras só foi suspensa a partir do momento em que não foram mais encontrados indivíduos (B. cocophilus) nas avaliações em laboratório. $B$. cocophilus foi capaz de sobreviver nas raízes dos coqueiros por pelo menos 118 e 133 dias após o corte (DAC), em Coruripe e São Miguel dos Milagres, respectivamente. Pode ter ocorrido a migração do B. cocophilus das raízes para o solo, visto que ele foi encontrado até 76 e 88 DAC no solo coletado em Coruripe e de São Miguel dos Milagres, respectivamente.

Palavras-chave: Bursaphelenchus cocophilus. Cocos nucifera. Doença do anel vermelho. Tempo de sobrevivência.

\footnotetext{
Discentes, Centro de Ciências Agrárias da Universidade Federal de Alagoas, CECA/UFAL, Rio Largo, AL, Brasil. E-mail: drih. bier@gmail.com,dtz.ufal@hotmail.com

2 Prof ${ }^{\text {, }}$ Centro de Ciências Agrárias, CECA/UFAL, Rio Largo, AL, Brasil. E-mail: adrianagduarte@hotmail.com

${ }^{3}$ Pesquisador, Embrapa Tabuleiros Costeiros, Unidade de Execução de Pesquisa e Desenvolvimento de Rio Largo, CPATC-UEP, Rio Largo, AL, Brasil. E-mail: anderson.marafon@embrapa.br

* Author for correspondence
} 


\section{Introduction}

The coconut palm (Cocos nucifera L.), a monocot from the Arecaceae family, is one of the most important palm species globally because it provides many agronomic, agribusiness, and socio-economic benefits, creating jobs and income throughout the year, as well as opportunities for a sustainable production of a valuable food source, within fragile ecosystems of coastal tropical regions (FAOLE; HARRIES, 2009).

In the last decade, cultivation of coconut palm and area harvested increased globally, particularly in the states of Bahia, Sergipe, Ceará, and Pará. Because of the tropical climate, these areas produce greater than $70 \%$ of the coconuts and comprise over $90 \%$ of the area planted with coconut palms in Brazil (MARTINS, 2011).

The need to revitalize the coconut palm crop in Brazil has become evident because of increasing industrial uses and consumption of fruits in natura. This situation requires a dramatic improvement in coconut production levels, which are currently very low, averaging 30 fruits per plant per year, with approximately six harvests per year (FONTENELE, 2005). Phytosanitary issues also pose an impediment to further development of this crop because of the potential for economic loss from pests and/or diseases (MARIANO; SILVEIRA, 2016).

Parasitism by nematodes is a phytosanitary issue with these fruit plants during their development. The nematological fauna in the rhizosphere of these plants is fairly differentiated and complex, with some species having a high reproductive capacity, which may over time cause a decline in plant health and a reduction in the useful life of the orchard (ARIEIRA et al., 2008).

Red ring disease is a highly lethal disease caused by the red ring nematode (Bursaphelenchus cocophilus (Cobb. 1919) Baujard, 1989, (Nematoda: Aphelenchoides). This is one of the main diseases that attacks the coconut palm and other palms of economic significance, such as the African oil palm (Elaeis guineensis Jacq.), and it has spread throughout the productive regions, limiting the coconut palm crop in various countries (WARWICK; LEAL, 2003). In 1954, the disease occurred for the first time in Brazil, in the state of Rio de Janeiro. It has since spread to the states of Bahia, Pernambuco, Sergipe, Alagoas, Ceara, and São Paulo (CASTRO et al., 2009; WARWICK, 2005).

B. cocophilus is a migrating endoparasite that can be found in any stage of development in the roots, stems, and leaf petioles in coconut palms, depending on the presence of biological vectors that facilitate the colonization of new hosts (WARWICK; TALAMINI, 2016). Generally, an attack by $B$. cocophilus on the roots reduces absorption and translocation of nutrients, leading to nutritional deficiency symptoms such as yellowing, discoloration, and spots on the leaves. An internal symptom is a red ring on the outside of the style, observed through a cross-sectional cut (FREITAS et al., 2012; DUARTE et al., 2008).

The main vectors of red rig nematode ( $B$. cocophilus) are adults of the South American palm weevil [Rhynchophorus palmarum Linnaeus, 1764 (Coleoptera: Curculionidae)]. These beetles carry the nematode in their bodies and colonize plant tissues, thereby transmitting the disease to healthy plants (GIBLIN-DAVIS et al., 2013, 2001; GRIFFITH; KOSHY, 1990). Transmission may also occur from direct contact between infected and healthy roots and/or through contaminated tools used to cut roots during management projects. According to Warwick and Talamini (2009), healthy plants are contaminated primarily through the feces or female oviposition on the leaf axils. The nematodes penetrate the plant tissues through cuts caused by people or by the insect itself, reinitiating the disease and vector cycle. Cut palm leaves exude compounds that attract the vector weevil $R$. palmarum. $B$. cocophilus are able to endoparasitically infect coconut and palm trees, moving within the style 
and feeding on the parenchyma cells, where they cause damage to the tissues. The damages caused by the nematode to the xylematic vessels induce the appearance of tyloses (irregular growths on the parenchyma cells), causing vascular occlusion, which, in the case of monocots, is irreversible because there are no exchange tissues to repair the damage (WARWICK; TALAMINI, 2016). Red ring disease host plants generally die after a few months. The infected coconut palms take 23 to 28 days to show the first symptoms of the disease and 3 to 4 months to die (FERREIRA et al., 2012).

Because red ring disease is lethal, management practices advocate for the eradication and destruction of the remains of the infected plants in order to reduce the potential for nematode population growth within the coconut palm grove. Upon confirming the diagnosis, the sick plants should be eliminated immediately with herbicide injected directly into the trunk or by felling the trees. These plants generally house $R$. palmarum larva, making it necessary to completely destroy the trees. However, even after the aerial part has been eradicated, the root system remains active for a certain period, facilitating the spread of the disease to healthy plants. This goal of this research was to determine the survival time of B. cocophilus within the soil and roots of recently eradicated coconut palms that were cultivated in two productive regions in the lower coastal region in the state of Alagoas.

\section{Materials and Methods}

Two experiments were conducted in coconut groves in cities in the lower coastal region of the state of Alagoas. The first experiment was conducted from September 2011 to March 2012 in São Miguel dos Milagres ( $9^{\circ} 15^{\prime} 56^{\prime \prime} \mathrm{S}, 35^{\circ} 22^{\prime} 23^{\prime \prime}$ $\mathrm{W}, 1 \mathrm{~m}$ altitude) in an area with sandy loam soil. The second was conducted in from October 2012 to March 2013 in Coruripe ( $10^{\circ} 07^{\prime} 32^{\prime \prime}$ S, 36 $6^{\circ} 10^{\prime} 32^{\prime \prime}$ $\mathrm{W}, 16 \mathrm{~m}$ altitude) in an area with clayey soil. The accumulated rainfall during the study period was
$649 \mathrm{~mm}$ in São Miguel dos Milagres and $141 \mathrm{~mm}$ in Coruripe.

Two coconut palms (one at each location) between 10 and 15 years old, with advanced symptoms of red ring disease, were selected and their aerial parts were incinerated. A hoe and an auger were used to collect root (50 g) and soil (100 g) samples from an area within a $30-\mathrm{cm}$ radius from the base of the style and a depth of $40 \mathrm{~cm}$.

In São Miguel dos Milagres, eight soil and root collections were performed at $0,21,42,64,88,112$, 133, and 167 days after felling (DAF). In Coruripe, seven soil and root collections were performed at $0,20,48,76,96,118$, and 138 DAF. Immediately after the sample collection, they were packed in plastic bags and taken to the Ecology and Insect Behavior Laboratory at the Federal University of Alagoas (LECOM/UFAL), where they were kept refrigerated at $5^{\circ} \mathrm{C}$ until they were processed within 3 days.

The extraction and nematode identification processes were based on descriptions provided by Oliveira and Freitas (2012), following the methodology developed by Jenkins (1964). The soil samples were sieved in a 20-mesh strainer and washed under a shower. The washing content was stored in a bucket. The suspension in the bucket was then mixed and passed through a 400-mesh strainer. The content retained in this strainer was recovered, centrifuged, and used for the analysis of the nematodes.

The roots were processed according to the methodology proposed by Hussey and Barker (1973). The root samples were washed in running water, cut into small ( 3 to $4 \mathrm{~cm}$ ) pieces, added to a multiprocessor with approximately $100 \mathrm{~mL}$ of distilled water and crushed for $30 \mathrm{~s}$. The material was subsequently passed through a 60-mesh strainer, followed by a 400 -mesh strainer, and then washed under a shower. The material retained in the 400-mesh strainer was recovered, centrifuged, and then used for the nematode analysis. The recovered 
suspensions were stored in test tubes and weighed on an analytical balance, with their masses adjusted by adding distilled water.

To separate the nematodes, the tubes were centrifuged for $5 \mathrm{~min}$ at $1,818 \mathrm{rpm}$ in a CENTRIBIO 80-2B centrifuge. After centrifugation, the supernatants were recovered and transferred to prelabeled beakers. Upon precipitating the remains in the test tubes, a sucrose solution $\left(425 \mathrm{~g} \cdot \mathrm{L}^{-1}\right)$ was added and it was once again centrifuged at $1,818 \mathrm{rpm}$ for $1 \mathrm{~min}$. This procedure was repeated one more time, recovering the supernatants from each sample, which were then passed through a 400-mesh strainer and washed with a shower (COOLEN; D'HERDE, 1972). The material retained in this strainer was transferred to plastic containers, to which TAF $(5 \%$ triethanolamine, $5 \%$ alcohol, $75 \%$ water and $15 \%$ formaldehyde) was added as a preservative, to a volume of approximately $20 \mathrm{~mL}$.

The volumes (in $\mathrm{mL}$ ) that were recovered from each root and soil sample were measured in graduated beakers. Prior to taking a sample for the reading and counting of nematodes, the samples were homogenized by blowing the liquid with a pipette.

A binocular microscope (LEICA CME model) with 100X magnification and a Kácil CCS-01 model cell counter was used to estimate the number of $B$. cocophilus juveniles. The readings were taken on two Peter's counting slides, each containing 1.0 $\mathrm{mL}$ of the sample.

The means of the data were statistically analyzed using TUKEY test $(\rho \leq 0,05)$, using the program ASSISTAT version 7.6 (SILVA; AZEVEDO, 2002).

\section{Results and Discussion}

The numbers of B. cocophilus found in the roots collected in São Miguel dos Milagres/AL were significantly greater $(\rho \leq 0,05)$ in the first five collections ( $0,21,42,64$ and 88 days after felling), than they were in the latter collections, when $100 \%$ of the samples analyzed were contaminated. Root contamination occurred in $100 \%$ of the samples until $88 \mathrm{DAF}$, when the average population was 453.12 B. cocophilus per $50 \mathrm{~g}$ of roots (Table 1).

B. cocophilus are highly capable of surviving in coconut palm tissues for a considerable amount of time, even 88 days after the destruction of the aerial portion (Table 1), thereby increasing the risk of contaminating other plants in the grove. Duarte et al. (2008) also found elevated levels of root contamination by B. cocophilus (95 and $83.3 \%$, respectively) at the time that red ring infected coconut palms were cut; these plants continued to be highly contaminated for approximately 50 days.

Within the root samples, there was a significant reduction in the $B$. cocophilus population from the fifth (88 DAF) to the sixth collection (112 DAF), decreasing from 453.12 to 11.79 nematodes per 50 $\mathrm{g}$ of roots, respectively. In the sixth and seventh collections (112 and 133 DAF, respectively) 50\% of the root samples were contaminated and on the eighth collection (167 DAF) no B. cocophilus were found. Although the average numbers of $B$. cocophilus were significantly lower in the 112 and 133 DAF collections (11.79 and 13.08 nematodes per $50 \mathrm{~g}$ of roots, respectively) than they were in previous collections, it wasn't until the eighth collection (167 DAF) that no individuals were found in the samples. This finding is particularly interesting because until the seventh collection (133 DAF) the nematodes remained alive in the roots, continuing the risk of spreading the pathogen (Table 1). 
Table 1. Average number ( $\pm \mathrm{SE}$ ) of Bursaphelenchus cocophilus juveniles in $50 \mathrm{~g}$ of roots collected from coconut palms affected by red ring disease in São Miguel dos Milagres/AL, 2012.

\begin{tabular}{cccccc}
\hline $\begin{array}{c}\text { Days after } \\
\text { felling (DAF) }\end{array}$ & $\begin{array}{c}\text { No. of } \\
\text { repetitions }\end{array}$ & $\begin{array}{c}\text { \% of samples } \\
\text { contaminated }\end{array}$ & Maximum & Minimum & Mean $( \pm$ SE)* \\
\hline $\mathbf{0}$ & 12 & 100 & 552.5 & 114 & $330.33 \pm 39.96 \mathrm{a}$ \\
$\mathbf{2 1}$ & 12 & 100 & 845.5 & 1.04 & $480.50 \pm 80.00 \mathrm{a}$ \\
$\mathbf{4 2}$ & 12 & 100 & 693.5 & 18.5 & $387.50 \pm 60.57 \mathrm{a}$ \\
$\mathbf{6 4}$ & 12 & 100 & 690.0 & 38.0 & $289.50 \pm 62.83 \mathrm{a}$ \\
$\mathbf{8 8}$ & 12 & 100 & 867.0 & 232.5 & $453.12 \pm 55.74 \mathrm{a}$ \\
$\mathbf{1 1 2}$ & 12 & 50 & 63.0 & 0.0 & $11.79 \pm 5.90 \mathrm{~b}$ \\
$\mathbf{1 3 3}$ & 12 & 50 & 54.0 & 0.0 & $13.08 \pm 4.60 \mathrm{~b}$ \\
$\mathbf{1 6 7}$ & 12 & 0 & 0.0 & 0.0 & $0.00 \pm 0.00 \mathrm{~b}$ \\
\hline
\end{tabular}

* Means followed by different letters differ from one another using Tukey’s test $(\mathrm{p} \leq 005)$. CV $=19.75 \%$.

Only a small number of $B$. cocophilus are required for a full establishment of red ring disease (GRIFFITH, 1968). B. cocophilus can survive in autoclaved soil, at temperatures of approximately $25^{\circ} \mathrm{C}$, for approximately 7 days (GRIFFITH, 1987). However, the nematodes can live for up to 80 days in style tissue extracts with or without the addition of D-Glucose or Lactose. They can also be cultivated for up to 4 weeks in a substrate of immature coconut fruits or in pieces of the rachis (GIBLIN-DAVIS et al., 1989).

This research showed that $B$. cocophilus were able to survive in the roots of dead coconut palms for a minimum of 133 DAF, in São Miguel dos Milagres/AL. Ferreira et al. (1998) recommend the immediate elimination of the contaminated plants by cutting or burning the aerial parts. When no $B$. cocophilus are found, there should be an additional waiting period of at least 167 days before planting new coconut palm seedlings.

There were significant differences $(\rho \leq 0,05)$ between the populations of $B$. cocophilus collected in the soil. In the first collection, taken on the date that the contaminated plant was eradicated, the average population size was 5.12 nematodes per $100 \mathrm{~g}$ of soil. In the second and fourth collections (21 and 64 DAF, respectively), the numbers of $B$. cocophilus were significantly greater (16.41 and 11.16 nematodes per $100 \mathrm{~g}$ of soil, respectively) than those in the other collections. In the fifth collection (88 DAF), there were 5.25 nematodes per $100 \mathrm{~g}$ of soil, with $41.67 \%$ of the samples contaminated. Nematodes were not found in any of the samples from the sixth, seventh, and eight collections (112, 133, and 167 DAF (Table 2).

The presence of $B$. cocophilus in the soil samples from the first five collections indicated that the nematodes migrated from the infected root tissues to the soil. Accordingly, it can be surmised that $B$. cocophilus are able to survive in the soil for at least $88 \mathrm{DAF}$, in São Miguel dos Milagres/AL. During this period, the pathogen may spread by the movement of B. cocophilus through the soil, which mainly depends on the soil texture and moisture. Soils with high clay contents are unfavorable to nematodes because they limit mobility and are easily saturated which reduces the amount of oxygen in the soil. Although sandy soils have large fluctuations in moisture because they are well-drained, nematodes cause the most damage in areas with sandy soils (WARWICK et al., 1998). Contamination of healthy coconut palm roots may occur as the nematodes spread through the soil. The majority of the farming areas are in regions with sandy soils that also have high rainfall indexes, both of which facilitate the spread of the pathogen. Additionally, root contact between healthy and contaminated plants can transmit B. cocophilus (WARWICK; BEZERRA, 1992). 
Table 2. Average number ( \pm SE) of Bursaphelenchus cocophilus juveniles in $100 \mathrm{~g}$ of soil collected from coconut palms affected by red ring disease in São Miguel dos Milagres/AL, 2012.

\begin{tabular}{cccccc}
\hline $\begin{array}{c}\text { Days after felling } \\
\text { (DAF) }\end{array}$ & $\begin{array}{c}\text { No. of } \\
\text { repetitions }\end{array}$ & $\begin{array}{c}\text { \% of samples } \\
\text { contaminated }\end{array}$ & Maximum & Minimum & Mean $( \pm$ SE)* \\
\hline $\mathbf{0}$ & 12 & 41.67 & 17.0 & 0.0 & $5.12 \pm 1.97 \mathrm{bc}$ \\
$\mathbf{2 1}$ & 12 & 58.33 & 45.0 & 0.0 & $16.41 \pm 5.08 \mathrm{a}$ \\
$\mathbf{4 2}$ & 12 & 16.67 & 13.0 & 0.0 & $1.91 \pm 1.63 \mathrm{bc}$ \\
$\mathbf{6 4}$ & 12 & 50.0 & 28.5 & 0.0 & $11.16 \pm 2.43 \mathrm{a}$ \\
$\mathbf{8 8}$ & 12 & 41.67 & 27.0 & 0.0 & $5.25 \pm 2.33 \mathrm{bc}$ \\
$\mathbf{1 1 2}$ & 12 & 0.0 & 0.0 & 0.0 & $0.00 \pm 0.0 \mathrm{c}$ \\
$\mathbf{1 3 3}$ & 12 & 0.0 & 0.0 & 0.0 & $0.00 \pm 0.0 \mathrm{c}$ \\
$\mathbf{1 6 7}$ & 12 & 0.0 & 0.0 & 0.0 & $0.00 \pm 0.0 \mathrm{c}$ \\
\hline
\end{tabular}

* Means followed by different letters differ from one another using Tukey's test $(\mathrm{p} \leq 005)$. CV $=12.49 \%$.

The number of B. cocophilus found in the soil of infected coconut palms is generally very low, as observed by Kastelein (1986), who found between 0 and 20 nematodes per $100 \mathrm{~g}$ of soil, at a depth of 30 $40 \mathrm{~cm}$. During the rainy season, the nematodes were located closer to the soil surface. The nematodes that were able to survive inside the roots had optimum protection against dehydration, as long as their host tissues remained active.

The number of $B$. cocophilus in root samples collected from Coruripe/AL on the date of infected coconut palm eradication (734.4 nematodes per $50 \mathrm{~g}$ of roots) was significantly greater $(\rho \leq 0,05)$ than that from all the other collections. From the time the plant was cut, the population size of red ring nematodes decreased, and the numbers in the second and third collections (20 and 48 DAF) were significantly greater $(\rho \leq 0,05)$ than those in the following collections. In the fourth collection (76 DAF), the average population size of $B$. cocophilus declined significantly to $13.37 \pm 1.37$ nematodes per $50 \mathrm{~g}$ of roots (Table 3 ).

The high rate of contamination by B. cocophilus, which was found in $100 \%$ of the root samples up to $96 \mathrm{DAF}$, shows the longevity of the nematode within the root tissues of the coconut palm. According to Ferraz et al. (2010), when the roots were not destroyed, the nematodes that were in the beginning or middle of their lifecycle were able to reach maturity. Each month that the nematodes persisted within the roots and soil represented an additional lifecycle. Therefore, in infested areas, the destruction of the root system immediately after the eradication of the plant may drastically reduce the potential of nematode population increases.

There were significant reductions in the average population size of B. cocophilus from the first to the second and from the third to the fourth collections, when 13.37 nematodes per $50 \mathrm{~g}$ of roots were found. Nematodes were absent from the samples only in the seventh collection (138 DAF). Probably, the faster reduction in the nematode population in the roots collected in Coruripe than in São Miguel dos Milagres occurred due to the low rainfall index of Coruripe, that was about five times less than the rainfall index of São Miguel do Milagres. As the nematodes survival depends on the amount of moisture in the soil, the low soil humidity in Coruripe possibly contributed to this faster reduction of the nematode population in the roots at that location. 
Table 3. Average number ( $\pm \mathrm{SE}$ ) of Bursaphelenchus cocophilus juveniles in $50 \mathrm{~g}$ of roots collected from coconut palms affected by red ring disease, Coruripe/AL, 2013.

\begin{tabular}{cccccc}
\hline $\begin{array}{c}\text { Days after } \\
\text { felling (DAF) }\end{array}$ & $\begin{array}{c}\text { No. of } \\
\text { repetitions }\end{array}$ & $\begin{array}{c}\text { \% of samples } \\
\text { contaminated }\end{array}$ & Maximum & Minimum & Mean ( \pm SE)* \\
\hline $\mathbf{0}$ & 4 & 100 & 1164.0 & 517.5 & $734.40 \pm 15.96 \mathrm{a}$ \\
$\mathbf{2 0}$ & 4 & 100 & 418.0 & 161 & $238.62 \pm 25.30 \mathrm{~b}$ \\
$\mathbf{4 8}$ & 4 & 100 & 247.5 & 42.5 & $165.62 \pm 30.37 \mathrm{~b}$ \\
$\mathbf{7 6}$ & 4 & 50 & 31.0 & 22.3 & $13.37 \pm 1.37 \mathrm{c}$ \\
$\mathbf{9 6}$ & 4 & 100 & 36.0 & 20.5 & $27.12 \pm 3.73 \mathrm{c}$ \\
$\mathbf{1 1 8}$ & 4 & 50 & 36.0 & 0.0 & $14.50 \pm 1.65 \mathrm{c}$ \\
$\mathbf{1 3 8}$ & 4 & 0 & 0.0 & 0.0 & $0.00 \pm 0.0 \mathrm{c}$ \\
\hline
\end{tabular}

* Means followed by different letters differ from one another using Tukey's test $(\mathrm{p} \leq 005)$. CV $=12.38 \%$.

These results corroborate those of Warwick et al. (1998), who found that, in field conditions, nematodes can remain active in the coconut palm style for up to 130 days after the plant is cut.

When nematodes are present within the soil, their population numbers tend to increase according to the availability of susceptible hosts with healthy tissues as food sources. As obligatory parasites, nematodes will decrease in the soil in the absence of a host plant, or when environmental conditions become unfavorable (FERRAZ et al., 2010).

Even in the absence of a live host, $B$. cocophilus were able to survive in the decomposing roots of coconut palms for a minimum of 118 DAF. These data corroborate with those found by Esser and Meredith (1987) who stated that B. cocophilus are able to survive in decomposing palm tissues for more than 90 days. Live B. cocophilus were recovered in the roots 1 year after the removal of the aerial part. Therefore, the destruction of the cultural remains must be done to eliminate the inoculum source, preventing the spread of the disease in nearby areas.
The largest average population sizes of $B$. cocophilus in the soil were found in the first and fourth collections (76 DAF), when 12.75 and 12.62 nematodes per $100 \mathrm{~g}$ of soil were found, respectively. From the fifth (96 DAF) though the seventh (138 DAF) collection, none of the samples were contaminated (Table 4).

These results contradict those described by Griffith (1987) who affirmed that the B. cocophilus cannot survive up to 7 days in autoclaved soil and also those of Giblin-Davis et al. (1989) which found that nematode does not survive in the soil for more than 2-3 days under field conditions and may move on its own at approximately $5.6 \mathrm{~mm} \cdot \mathrm{h}^{-1}$ in the soil and approximately $0.25 \mathrm{~mm} \cdot \mathrm{h}^{-1}$ in the roots. Our hypothesis is that $B$. cocophilus could migrate continuously from the roots of the affected coconut palms to the soil for at least 76 DAF.

Griffith and Koshy (1990) found that, although the roots can be infected artificially, this is not the normal mode of disease occurrence in the field, and that the nematodes do not persist in the soil in large enough numbers for further infection to occur. 
Table 4. Average number ( \pm SE) of Bursaphelenchus cocophilus juveniles in $100 \mathrm{~g}$ of soil collected from coconut palms affected by red ring disease, Coruripe/AL, 2013.

\begin{tabular}{cccccc}
\hline $\begin{array}{c}\text { Days after } \\
\text { felling (DAF) }\end{array}$ & $\begin{array}{c}\text { No. of } \\
\text { repetitions }\end{array}$ & $\begin{array}{c}\text { \% of samples } \\
\text { contaminated }\end{array}$ & Maximum & Minimum & Mean $( \pm$ SE)* \\
\hline $\mathbf{0}$ & 4 & 100 & 14.0 & 11.0 & $12.75 \pm 1.97 \mathrm{a}$ \\
$\mathbf{2 0}$ & 4 & 50 & 9.0 & 0.0 & $4.50 \pm 1.08 \mathrm{~b}$ \\
$\mathbf{4 8}$ & 4 & 25 & 10.0 & 0.0 & $2.50 \pm 1.30 \mathrm{~b}$ \\
$\mathbf{7 6}$ & 4 & 100 & 21.0 & 9.5 & $12.62 \pm 1.43 \mathrm{a}$ \\
$\mathbf{9 6}$ & 4 & 0.0 & 0.0 & 0.0 & $0.00 \pm 0.00 \mathrm{~b}$ \\
$\mathbf{1 1 8}$ & 4 & 0.0 & 0.0 & 0.0 & $0.00 \pm 0.00 \mathrm{~b}$ \\
$\mathbf{1 3 8}$ & 4 & 0.0 & 0.0 & 0.0 & $0.00 \pm 0.00 \mathrm{~b}$ \\
\hline
\end{tabular}

* Means followed by different letters differ from one another using Tukey's test $(\mathrm{p} \leq 005)$. CV $=11.59 \%$.

Many species of nematodes are capable of surviving in an inactive state, keeping their metabolism rates very low or practically zero (FERRAZ et al., 2010). Phytonematodes move randomly in the soil, combining periods of activity with quiescent periods, until the host plant is located. The nematode will move in the direction of an attractive chemical stimulus (FREITAS et al., 2012).

As the nematodes survival depends on the amount of moisture in the soil, we can suggest that locations with major rainfall indexes allow longer survival in the absence of the host.

\section{Conclusions}

After the eradication of coconut palms with advanced symptoms of red ring disease, under the climatic conditions of the lower coastal region in the state of Alagoas, it was concluded that:

B. cocophilus were found in the roots samples collected in the cities of Coruripe and São Miguel dos Milagres until 118 and 133 days after felling, respectively;

B. cocophilus were found in the soil samples collected in the cities of Coruripe and São Miguel dos Milagres until for 76 and 88 days after felling, respectively. Probably, the red ring nematode was able to migrate from the root tissues of the affected plants to the soil;

The persistence time and population sizes of $B$. cocophilus were greater in the roots than those in the rhizosphere of plants affected by red ring disease. Therefore, the destruction of the coconut cultural remains must be done to eliminate the inoculum source, preventing the spread of the disease in nearby areas.

\section{References}

ARIEIRA, C. R. D.; MOLINA. R. O.; COSTA, A. T. Nematóides causadores de doenças em frutíferas. Agroambiente On-line, Boa Vista, v. 2, n. 1, p. 46-56, 2008.

CASTRO, J. M. C.; LIMA, C. R. F.; SANTANA, M. L. M. P. Nematoide do anel vermelho do coqueiro e medidas de manejo. Petrolina: Embrapa Semiárido, 2009. 4 p. (Instruções técnicas, 88).

COOLEN, W. A.; D'HERDE, C. J. A method for the quantitative extraction of nematodes from plant tissue. Ghent: Nematologyand Entomology Research Station, 1972. $77 \mathrm{p}$.

DUARTE, A. G.; LIMA, I. S.; ARAÚJO JÚNIOR, J. V.; DUARTE, A. G.; ALBUQUERQUE, A. L. S.; CRUZ, M. M. Disposição do nematóide Bursaphelenchus cocophilus (Cobb) Baujard, em coqueiros portadores da doença anel-vermelho. Revista Brasileira de Fruticultura, Jaboticabal, v. 30, n. 3, p. 622-627, 2008. 
ESSER, R. P.; MEREDITH, J. A. Red ring nematodes. Gainesville: Florida Department of Agriculture and Consumer Services, Division of Plant Industry, 1987. 4 p. (Nematology Circular, 141).

FAOLE, M.; HARRIES, H. Farm and forestry production and marketing profile for coconut (Cocos nucifera). In: ELEVITH, C. R. (Ed.). Specialty crops for pacific island agroforestry. Holualoa: Permanent Agriculture Resources, PAR, 2009. 248 p.

FERRAZ, S.; FREITAS, L. G.; LOPES, E. A.; ARIEIRA, C. R. D. Manejo sustentável dos fitonematoides. Viçosa, MG: Ed. UFV, 2010. 306 p.

FERREIRA, J. M. S.; WARWICK, D. R. N.; SIQUEIRA, L. A. (Ed.). A cultura do coqueiro no Brasil. 2. ed. Brasília: EMBRAPA/CPATC, 1998. 292 p.

FERREIRA, P. A.; FERRAZ, S.; FREITAS, L. G. Sintomas causados por fitonematoides. In: ZAMBOLIM, L.; JESUS JÚNIOR, W. C.; PEREIRA, O. L. O essencial da fitopatologia: agentes causais. Viçosa, MG: UFV, DPF, 2012. v. 1, p. 203-222.

FONTENELE, R. E. S. Cultura do coco no Brasil: caracterização do mercado atual e perspectivas futuras. In: CONGRESSO DA SOCIEDADE BRASILEIRA DE ECONOMIA E SOCIOLOGIA RURAL: INSTITUIÇÕES, EFICIÊNCIA, GESTÃO E CONTRATOS NO SISTEMA AGROINDUSTRIAL, 43., 2005, Ribeirão Preto. Anais... Ribeirão Preto: SOBER, 2005. p. 1-10.

FREITAS, L. G.; OLIVEIRA, R. D. L.; FERRAZ, S. Nematoides como patógenos de plantas. In:ZAMBOLIM, L.; JESUS JÚNIOR, W. C.; PEREIRA, O. L. O essencial da fitopatologia: agentes causais. Viçosa, MG: UFV, DPF, 2012. v. 2, p. 89-128.

GIBLIN-DAVIS, R. M. Borers of palms. In: HOWARD, F. W.; MOORE, D.; GIBLIN-DAVIS, R. M.; ABAD, R. G. Insects on palms. Wallingford: CABI Publishing, 2001. p. 267-304.

GIBLIN-DAVIS, R. M.; GERBER, K.; GRIFFITH, R. In vivo and in vitro culture of the ring nematode, Rhadinaphelenchus cocophilus. Nematropica, Auburn, v. 19, n. 2, p. 135-142, 1989.

GIBLIN-DAVIS, R. M.; KANZAKI, N.; DAVIES, K. A. Nematodes that ride insects: unforeseen consequences of arriving species. Florida Entomologist, Gainesville, v. 96, n. 3, p. 770-780, 2013.

GRIFFITH, R. Red ring disease of coconut palm. Plant Disease, St. Paul, v. 71, n. 2, p. 193-196, 1987.
. The relationship between the red ring nematode and the palm weevil. Journal Agricultural Society of Trinidad and Tobago, Porto of Spain, v. 68, n. 3, p. 342356, 1968.

GRIFFITH, R.; KOSHY, P. K. Nematode parasites of coconut and other palms. In: LUC, M.; SIKORA, R. A.; BRIDGE, J. Plant parasitic nematodes in subtropical and tropical agriculture. Wallingford: CAB International, 1990, p. 363-386.

HUSSEY, R. S.; BARKER, K. R. A. Comparison of methods for collecting inoculum of Meloidogyne spp. Including a new technique. Plant Disease Reporter, Beltsville, v. 57, n. 12, p. 1025-1028, 1973.

JENKINS, W. R. A rapid centrifugal-flotation technique for separating nematodes from soil. Plant Disease Reporter, Beltsville, v. 48, n. 9, p. 692-692, 1964.

KASTELEIN, P. Observations on the red ring disease in coconut palms in Suriname. De Surinaamse Landbouw, Paramaribo, v. 34, n. 1, p. 40-53, 1986.

MARIANO, R. L. R.; SILVEIRA, E. B. Doenças do coqueiro. In: KIMATI, H.; AMORIM, L.; REZENDE, J. A. M.; BERGAMIN FILHO, A.; CAMARGO, L. E. A. Manual de fitopatologia: doenças das plantas cultivadas. São Paulo: Agronômica Ceres, 2016. p. 271-281.

MARTINS, C. R. Evolução da produção de coco no Brasil e o comércio internacional: Panorama 2010. Aracaju: Embrapa Tabuleiros Costeiros, 2011. 28 p. (Documentos, 164).

OLIVEIRA, R. D. L.; FREITAS, L. G. Métodos empregados em Fitonematologia. In: ZAMBOLIM, L.; JESUS JÚNIOR, W. C.; PEREIRA, O. L. O essencial da fitopatologia: agentes causais. Viçosa, MG: UFV, DPF, 2012. v. 2, p. 355-376.

SILVA, F. A. S. E.; AZEVEDO, C. A. V. Versão do programa computacional ASSISTAT para o sistema operacional Windows. Revista Brasileira de Produtos Agroindustriais, Campina Grande, v. 4, n. 1, p. 71-78, 2002.

WARWICK, D. R. N. Principais características do anelvermelho e da murcha-de-fitomonas. Aracaju: Embrapa Tabuleiros Costeiros, 2005. 8 p. (Comunicado técnico, 38).

WARWICK, D. R. N.; BEZERRA, A. P. T. Possible root transmission of the red ring nematode (Rhadinaphelenchus cocophilus) to coconut palms. Plant Disease, St. Paul, v. 76, n. 8, p. 809-811, 1992. 
WARWICK, D. R. N.; LEAL, E. C. Principais doenças letais. In: FERREIRA, J. M. S. (Ed.). Coco fitossanidade. Brasília: EMBRAPA, 2003. p. 51-62.

WARWICK, D. R. N.; LEAL, E. C.; RAM, C. Doenças do coqueiro. In: FERREIRA, J. M. S.; WARWICH, D. R. N.; SIQUEIRA, L. A. A cultura do coqueiro no Brasil. 2. ed. Brasília: EMBRAPA-CPATC, 1998. p. 262-292.
WARWICK, D. R. N.; TALAMINI, V. Doenças do coqueiro. Informe Agropecuário, Belo Horizonte, v. 37, n. 290, p. 48-61, 2016.

. Doenças e métodos de controle ajustados à baixa capacidade de investimentos dos pequenos produtores rurais. In: CINTRA, F. L. D.; FONTES, H. R.; PASSOS, E. E. M.; FERREIRA, J. M. S. Fundamentos tecnológicos para a revitalização das áreas cultivadas com coqueiro gigante no Nordeste do Brasil. Aracaju: Embrapa Tabuleiros Costeiros, 2009. p. 157-190. 